\title{
Inhibition of Inflammatory Changes in Human Myometrial Cells by Cell Penetrating Peptide and Small Molecule Inhibitors of NFKB
}

\author{
Leo R. I. Gurney ${ }^{1 *}$, Julie Taggart ${ }^{1}$, Wing-Chiu Tong ${ }^{1}$, Arwyn T. Jones ${ }^{2}$, \\ Stephen C. Robson ${ }^{3}$ and Michael J. Taggart ${ }^{1 *}$
}

${ }^{1}$ Institute of Genetic Medicine, Newcastle University, Newcastle upon Tyne, United Kingdom, ${ }^{2}$ School of Pharmacy and Pharmaceutical Sciences, Cardiff University, Cardiff, United Kingdom, ${ }^{3}$ Institute of Cellular Medicine, Newcastle University, Newcastle upon Tyne, United Kingdom

\section{OPEN ACCESS}

Edited by:

Massimo Gadina

National Institute of Arthritis and Musculoskeletal and Skin Diseases (NIAMS), United States

Reviewed by:

Nardhy Gomez-Lopez, Wayne State University School of Medicine, United States Ashley K. Boyle, University College London, United Kingdom

*Correspondence: Leo R. I. Gurney leo.gurney@doctors.org.uk Michael J. Taggart michael.taggart@ncl.ac.uk

Specialty section: This article was submitted to Inflammation,

a section of the journal

Frontiers in Immunology

Received: 27 September 2018 Accepted: 03 December 2018 Published: 20 December 2018

Citation:

Gurney LRI, Taggart J, Tong W-C Jones AT, Robson SC and Taggart MJ

(2018) Inhibition of Inflammatory

Changes in Human Myometrial Cells by Cell Penetrating Peptide and Small Molecule Inhibitors of $N F_{K} B$. Front. Immunol. 9:2966. doi: 10.3389/fimmu.2018.02966
Complications arising from Preterm Birth are the leading causes of neonatal death globally. Current therapeutic strategies to prevent Preterm Birth are yet to demonstrate success in terms of reducing this neonatal disease burden. Upregulation of intracellular inflammatory pathways in uterine cells, including those involving nuclear factor kappa-B (NFKB), have been causally linked to both human term and preterm labor, but the barrier presented by the cell membrane presents an obstacle to interventions aimed at dampening these inflammatory responses. Cell penetrating peptides (CPPs) are novel vectors that can traverse cell membranes without the need for recognition by cell surface receptors and offer the ability to deliver therapeutic cargo internal to cell membranes. Using a human uterine cell culture inflammatory model, this study aimed to test the effectiveness of CPP-cargo delivery to inhibit inflammatory responses, comparing this effect with a small molecule inhibitor (Sc514) that has a similar intracellular target of action within the NFKB pathway (the IKK complex). The CPP Penetratin, conjugated to rhodamine, was able to enter uterine cells within a 60 min timeframe as assessed by live confocal microscopy, this phenomena was not observed with the use of a rhodamine-conjugated inert control peptide $\left(\mathrm{GC}(\mathrm{GS})_{4}\right)$. Penetratin CPP conjugated to an IKK-inhibitory peptide (Pen-NBD) demonstrated ability to inhibit both the IL1 $\beta$-induced expression of the inflammatory protein COX2 and dampen the expression of a bespoke array of inflammatory genes. Truncation of the CPP vector rendered the CPP-cargo conjugate much less effective, demonstrating the importance of careful vector selection. The small molecule inhibitor Sc514 also demonstrated ability to inhibit COX2 protein responses and a broad down-regulatory effect on uterine cell inflammatory gene expression. These results support the further exploration of either CPP-based or small molecular treatment strategies to dampen gestational cell inflammatory responses in the context of preterm birth. The work underlines both the importance of careful selection of CPP vector-cargo combinations and basic testing over a broad time and concentration range to ensure effective responses. Further work should demonstrate the effectiveness of CPP-linked cargos to dampen alternative pathways of inflammation linked to Preterm Birth such as MAP Kinase or AP1.

Keywords: preterm birth, nuclear factor kappa B, cell penetrating peptide, tocolytic, myometrial cell 


\section{INTRODUCTION}

Preterm birth, or birth before 37 weeks completed gestation as defined by the World Health Organization, is the main cause of neonatal death in developed countries and presents an enormous global problem (1). Being born too soon can confer significant clinical deficits throughout life, leading to neuro-developmental disorders such as cerebral palsy, learning impairment and visual disorders; with such problems being more likely to occur with greater frequency and severity at earlier gestations of birth (2).

Preterm birth is a syndrome best understood as the final endpoint of several possible pathophysiological events. It can be initiated by an array of processes including: uterine overdistension, utero-placental hemorrhage or ischaemia, maternal stress, cervical insufficiency, and inflammation with or without clinically apparent infection (3). Parallel to this, there is evidence to suggest that the processes that drive spontaneous human labor, whether at term or preterm, have an inflammatory basis. Macrophage and neutrophil numbers in human fetal membranes, myometrium and cervix are increased in tissue derived from laboring patients $(4,5)$ and such invasion leads to increases in local cytokine and chemokine production including increases in IL1 $\beta$, IL8, and TNF $\alpha$ (6). These changes may precipitate, or contribute to, a sequence of uterine activation processes leading to labor (7). Furthermore, invasion of the decidua by these cell types occurs in animal models of preterm birth and precedes the onset of labor (8); although whether this invasion is a cause or consequence of labor remains to be fully defined (9). The inflammatory milieu provoked within the uterine environment has been reported to upregulate varied pro-inflammatory pathways in uterine and placental cells including signaling pathways involving p38 MAP kinase (p38 MAPK) and Activator Protein 1 (AP1) $(10,11)$. Most importantly, upregulation of intracellular pathways involving the transcription factor nuclear factor $\kappa \mathrm{B}(\mathrm{NF} \mathrm{B})$ are suggested to play a central role in the sequelae of inflammation-associated preterm birth (12).

$N F \kappa B$ proteins are a family of five structurally related transcription factors named p65 (Rel A), RelB, c-Rel, p50 (NFkB$1)$, and p52 (NFкB-2) present in nearly all mammalian cells that play a ubiquitous role in inflammatory and infectious responses (13). All NFKB proteins exist in the form of heterogeneous dimers, the most commonly described of which is p65/p50 which is known to activate the expression of pro-inflammatory genes within the uterus (14). Within the canonical NFkB pathway interaction between cell surface receptors and lipopolysaccharide (LPS), or pro-inflammatory cytokines such as IL-1 $\beta, \mathrm{TNF} \alpha$, or IL6 activates the IkB kinase complex (IKK complex) (13). This kinase complex consists of two catalytic subunits (IKK $\alpha$ \& IKK $\beta$ ) each containing a six amino acid segment LDWSWL, known as the Nemo Binding Domain (NBD), which forms the basis of their binding site with the regulatory NFKB essential modulator (NEMO) scaffold protein. Activation of IKK leads to the targeted phosphorylation of $\operatorname{IkB} \alpha$ allowing for the ubiquitination and subsequent degradation of this anchoring protein by the proteasome. This step allows it to translocate to the nucleus of the cell, a process enhanced by the IKK-dependent phosphorylation of $\mathrm{p} 65$. Once in the cell nucleus, NFкB binds to target gene promoters regulating the expression of inflammatory genes including those that transcribe IL1 $\beta$, TNF $\alpha$, IL6, IL8, CXCL2, MMP 9, and COX2 (15). Due to the presence of $\kappa B$

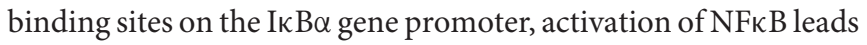

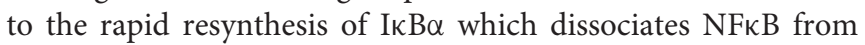
DNA complexes and is shuttled out of the nucleus in an inactive complex (16).

Amongst the evidence supporting the role of NFאB activation in labor are observations from in vitro studies on human myometrial cells: activation of NFKB has been shown to promote the expression of the inducible prostaglandin synthase enzyme cyclooxygenase 2 (COX2) leading to subsequent increases in prostaglandin production in these cells (17). Prostaglandins $\mathrm{E} 2$ and $\mathrm{F} 2 \alpha$ promote uterine contractions and their increased production within reproductive tissues is associated with the onset of human labor (18), thus increases in COX2 expression are thought to correspond to both inflammatory and contractile responses in the myometrium during human labor.

Myometrial cell NFKB activation also promotes the increased production of pro-inflammatory cytokines including IL-6 and IL-8 (19), matrix metalloproteinases (20), and up-regulates the expression of mRNA encoding genes associated with labor including the oxytocin receptor and gap junction proteins (21, 22).

Agents aimed at the acute prevention of preterm birth are a class of drugs referred to as tocolytics. Despite their use in more than 3000 clinical trials over 60 years, tocolytic agents have yet to demonstrate significant improvements in neonatal outcome and their use is frequently associated with an unacceptably high frequency of unwanted sequelae (23). This leaves an urgent need for the exploration of new therapeutic strategies aimed at targeting the molecular pathways whose upregulation is linked to preterm birth.

Peptides targeting protein-protein interactions that regulate cellular processes are gaining increasing traction as therapeutic entities that target a number of diseases. As biological molecules they offer very high selectivity and specificity and are relatively cheap to manufacture (24) A major barrier to the development of new peptides as pharmaceuticals is presented by the cell membrane: the lipid bilayer can prevent the passage of therapeutics from extracellular space to intracellular targets that often lie within the cytosol of a cell. To overcome this obstacle requires a vector system that can deliver cargo to the cell cytosol either directly through the plasma membrane or through utilizing endocytosis as a portal to cytoplasm before mediating endocytic escape processes to reach the cytosol (25).

Cell Penetrating Peptides (CPPs) offer an attractive solution to this drug delivery puzzle: they are characterized as short peptides, usually $<30$ amino acids length, that have the ability to cross cell membranes without the need for recognition by cell surface receptors (26). CPPs have been shown to deliver cargo efficiently at low doses to a diverse range of cell types and a number of studies in varied clinical fields have confirmed the potential of $\mathrm{CPP}$-cargo conjugates as therapeutic agents (27). This has led to several CPP-based therapies being tested in phase 3 clinical trials for a diverse range of inflammatory conditions (28). Despite this, 
the effectiveness of CPP-linked therapy in gestational cells has yet to be examined in detail.

Amongst the broad array of cargoes that can be conjugated to CPPs and delivered intracellularly are molecules with the capability to block NFkB-dependent signaling (15). The best described CPP-cargo conjugate with NFKB inhibitory ability is the Nemo Binding Domain (NBD) peptide: an 11 amino acid residue peptide which was designed to span the NBD and therefore disrupt the interaction between the three IKK subunits within the NFKB canonical pathway, with the effect of inhibiting the inflammatory ligand-dependant activation of NFKB (29). The NBD peptide, conjugated to varied CPP vectors, has been shown to down-regulate elicited $\mathrm{NF} \kappa \mathrm{B}$ responses and thus improve physiological endpoints of inflammation both in vitro and in animal models of diseases as varied as Muscular Dystrophy and Parkinson's disease (30-32).

Small molecule inhibitors targeting several levels of the $\mathrm{NF \kappa B}$ pathway have been reported including those blocking the phosphorylation of $\operatorname{IkB} \alpha$ via IKK complex inhibition or preventing proteasome degradation of this molecule (33). Inhibitors have also been demonstrated that prevent NFкB localization to the nucleus or block post translational modifications of p65. The advantages of using small molecule drug inhibition include low immunogenicity and the possibility of attaining high oral bioavailability with the aim of inhibiting specific signaling pathways. However, high concentrations may be required to achieve therapeutic benefit; they may be poor at crossing biological barriers, and are often substrates for swift removal via drug efflux proteins (34).

The non-peptidic inhibitor Sc514 represents an established small molecule compound targeting NFKB mediated effects. It exerts action via inhibition of the IKK $\beta$ portion of the IKK complex and therefore putatively offers discrete inhibition of the NFKB pathway via a mechanism similar to the NBD peptide (35). It has demonstrated ability to significantly reduce LPS-stimulated $\mathrm{TNF} \alpha$ secretion in placentally-derived human primary cells (36), however it has yet to be broadly tested in a uterine cell setting. Thus, the use of this drug allows examination of the efficacy of a small molecule approach to inhibit NFKB-related inflammatory responses in myometrial cells, as well as offering a comparison with the CPP-cargo inhibitory approach presented by the NBD peptide.

With the intention of broadening the scope of antiinflammatory candidate agents available to be tested for their potential as treatments for preterm birth, the aims of this study were to: (i) first define the ability of CPPs to enter human myometrial cells and deliver the NBD peptide and (ii) subsequent to this, examine the effectiveness of CPP-NBD peptide conjugates in dampening NFKB related signaling compared to Sc514 in human myometrial cells.

\section{MATERIALS AND METHODS}

\section{Subjects \& Samples}

Ethical approval was obtained from Newcastle and North Tyneside Research Ethics Committee (10/H0906/71) to perform research on samples collected as part of the Newcastle Uteroplacental Tissue Bank. Human myometrial tissue was obtained from patients following written informed consent from nonlaboring women with uncomplicated, singleton pregnancies undergoing elective Cesarean section at term ( $\geq 37$ weeks gestation). Myometrial muscle strip biopsies approximately $1 \times$ $1 \mathrm{~cm}$ in size were taken from the upper portion of the lower segment uterine incision and placed in tissue collection buffer.

Biopsies were excluded from women with underlying medical or obstetric disease, women on any current medication, those with a body mass index outside range $20-35 \mathrm{~kg} / \mathrm{m}^{2}$, or who gave birth to a baby with weight below the 10th percentile or above the 90th percentile. Separate myometrial biopsies from 46 patients were included in the study.

\section{Preparation of Myometrial Cells}

Human myometrial biopsies were micro-dissected under a light microscope to isolate myometrial tissue from any remaining decidua. In a microbiological safety cabinet, tissue was cut into small fragments before adding $10 \mathrm{mls}$ warmed hanks balanced salt solution containing $10 \mathrm{mg}$ each of collagenase $1 \mathrm{~A}$ and XI (Sigma Aldrich, C7657, C9891) plus $20 \mathrm{mg}$ bovine serum albumin (Sigma Aldrich, A6003). This tissue digestion mix was placed in an orbital shaker at $110 \mathrm{rpm}$ for approximately $40 \mathrm{~min}$ at $37^{\circ} \mathrm{C}$. The sample was then triturated, filtered through a $70 \mu \mathrm{m}$ cell strainer into $10 \mathrm{ml}$ warmed media and centrifuged at $1,000 \mathrm{rpm}$ $(89 \times \mathrm{g})$ for $5 \mathrm{~min}$. The supernatant was discarded and cell pellet re-suspended in GlutaMAX cell culture media (Life Technologies 61965) containing 10\% FCS and Penicillin/Streptomycin until $80-90 \%$ confluent (37).

\section{Cell Penetrating Peptides}

CPP's were custom synthesized commercially and purchased from either EZ Biolabs (USA) or Abingdon Health Laboratory (UK) services. Rhodamine fluorophore cargo (excitation $561 \mathrm{~nm}$, emission $617 \mathrm{~nm}$ ) was labeled at the N-terminal end of either Penetratin or Pen(43-56) CPP. NBD or inactive NBD mutant cargo was conjugated at the $\mathrm{C}$-terminal end of either Penetratin or Pen(43-56) CPP. Aminohexanoic acid (Aca) was used as a linker between CPP and cargo. The amino acid structures of the peptides used in experimentation are detailed in Table $\mathbf{1 .}$

To test specificity of COX2 responses to the NBD peptide, the effect of a Penetratin-conjugated mutant version of the NBD peptide: Pen NBD (Mut), was examined. This peptide contains the substitution of two tryptophan (W) amino acid residues to alanine (A) thus rendering it unable to span the NBD and interfere with IKK related signaling toward NFкB (29).

To further investigate the importance of CPP vector structure for the delivery of biologically active cargo a truncated form of Penetratin CPP was conjugated to the NBD peptide: Pen(43-56)NBD (38).

\section{Live Cell Confocal Microscopy}

Primary human myometrial cells at passage $\mathrm{P} \leq 4$ were transferred into 4 or 8-well microscope Ibidi $\mu$-Slides (Thistle Scientific, IB80441 , IB-80821) and grown up to $80-90 \%$ confluency. Cells 
TABLE 1 | The nomenclature and amino acid structure of peptides used for experimentation.

\begin{tabular}{ll}
\hline Peptide name & Structure \\
\hline $\begin{array}{l}\text { Rhodamine labeled } \\
\text { Penetratin }\end{array}$ & Rhodamine-RQIKIWFQNRRMKWKK \\
$\begin{array}{l}\text { Rhodamine labeled } \\
\text { Pen-NBD }\end{array}$ & Rhodamine-RQIKIWFQNRRMKWKKTALDWSWLQTE \\
Rhodamine labeled & Rhodamine-RQIKIWFQNRRMKW-Aca- TALDWSWLQTE \\
Pen(43-56)- NBD & \\
Rhodamine labeled & Rhodamine- GSGSGSGSGC \\
GS 4 (GC) & \\
Pen-NBD & RQIKIWFQNRRMKWKKTALDWSWLQTE-NH2 \\
Pen-NBD Mutant & RQIKIWFQNRRMKWKKTALDASALQTE-NH2 \\
NBD & TALDWSWLQTE \\
Pen (43-56)-NBD & Ac-RQIKIWFQNRRMKW-Aca-TALDWSWLQTE-NH2 \\
Pen (43-56)-NBD & Ac-RQIKIWFQNRRMKW-Aca-TALDASALOTE-NH2 \\
Mutant &
\end{tabular}

Rhodamine fluorophore cargo (excitation $561 \mathrm{~nm}$, emission $617 \mathrm{~nm}$ ) is labeled at the $\mathrm{N}$ terminal end of Penetratin or Pen(43-56) CPP. NBD or inactive NBD mutant cargo is conjugated at the C-terminal end. Acyl (Ac), Aminohexanoic acid (Aca), Amide (NH2).

were washed in phosphate buffered saline and changed to serumreduced media $(0.1 \%$ FCS $)$ for $18-24 \mathrm{~h}$ (39). Cells were then loaded with $1 \mu \mathrm{M}$ Hoechst nuclear dye (Life Technologies, 33342) for $1 \mathrm{~h}$ and washed with PBS before transfer to the confocal microscope where they were maintained within a temperature-controlled chamber maintained at $37^{\circ} \mathrm{C}, 5 \% \mathrm{CO}_{2}$ on the stage of the inverted microscope.

Initial images were collected to assess baseline cellular autofluorescence prior to the addition of varying concentrations of fluorophore-CPP/fluorophore- CPP-Cargo/fluorophore-control peptide combinations (see Table 1 ) that were ready made up in serum-reduced cell media. Further images were captured $60 \mathrm{~min}$ following application. During imaging cells were placed in phenol red free Dulbecco modified eagle medium (Life Technologies, 21063) to reduce background glare.

To make a thorough assessment of fluorescent uptake throughout whole cells, all images were captured as a series of slices in the Z plane (range 3-10 slices per area selected, each slice $0.54 \mu \mathrm{m}$ apart) with the $40 \mathrm{x}$ objective using live cell spinning disk confocal microscopy (Andor Revolution XD coupled to an Olympus IX-81 inverted microscope; Andor Belfast UK). All images were digitally recorded with IQ2 software (Andor, Belfast, $\mathrm{UK})$.

\section{Cell Stimulation Experiments for Subsequent Protein or mRNA Extraction}

Primary human myometrial cells at passage $\leq \mathrm{P} 4$ were split equally between 6 or 12 well-plates and grown to $80-90 \%$ confluency. At this point media was changed to serum-reduced $(0.1 \%$ FCS $)$ media for 18 to $24 \mathrm{~h}$ before discarding from each well. Five hundred microliters of fresh media $(0.1 \%$ FCS $)$ was produced containing: Pen-NBD, Pen(43-56)-NBD, Sc514 (Tocris bioscience, 3318); or controls (equivalent volume DMSO, PenNBD Mutant, NBD alone) at indicated concentrations. The inhibitor/control media was added to wells as a pre-incubation step. After 1 h, $10 \mathrm{ng} / \mathrm{ml}$ IL1 $\beta$ (Peprotech, 200-01B), or equivalent volume DMSO vehicle, was added to each well.

For western blotting experiments cells were washed with PBS before being lysed using sucrose cell lysis buffer $(62.5 \mathrm{mM}$ Tris- $\mathrm{HCl}$ pH6.8, 2\% SDS, $10 \%$ saccharose) containing 20 $\mu \mathrm{l} / \mathrm{ml}$ protease inhibitor (Sigma Aldrich, P1860) and $5 \mu \mathrm{l} / \mathrm{ml}$ phosphatase inhibitor (Sigma Aldrich P2745) at times of 0/15/60/120/240 minute from cytokine stimulation.

For RNA array experiments, $4 \mathrm{~h}$ following cytokine stimulation cells were washed with PBS before RNA was extracted using the RNeasy Mini Kit (Qiagen, 74101) according to the manufacturers' protocol.

\section{Western Immunoblotting}

Cell lysate samples were sonicated and underwent Lowry assay to determine overall protein concentration before dilution in an equal volume of 2x Laemmli buffer (Tris pH6.8 $250 \mathrm{nM}$; SDS 4\% w/v; Glycerol 10\% v/v; $\beta$-mercaptoethanol; bromophenol blue). Ten micrograms of sample protein per lane was loaded onto a $1.5 \mathrm{~mm} 10 \%$ sodium dodecyl sulfate poly-acrylamide gel (SDSPAGE) before undergoing separation by electrophoresis, gels then underwent electrophoretic transfer to a methanol-activated polyvinylidine difluoride (PVDF) membrane.

Following a blocking step of washing membranes in 5\% non-fat dry milk in Tris-buffered saline with $0.1 \%$ Tween20 (TBS-T) for $1 \mathrm{~h}$ at room temperature, membranes were incubated overnight at $4{ }^{\circ} \mathrm{C}$ with primary anti-COX-2 antibody 1:500 (Cayman laboratories, CAY160112), anti-IкB- $\alpha$ antibody 1:500 (Santa Cruz, C21 Sc371) anti-phospho-P65 antibody 1:2000 (Cell Signaling, 3013), or anti-P65 antibody 1:15,000 (Santa Cruz, Sc372) in 1\% non-fat dry milk with TBS-T. After three washing steps with TBS-T, secondary antibody incubation occurred for $1 \mathrm{~h}$ at room temperature. Polyclonal horseradish peroxidise conjugated goat anti-mouse immunoglobulin 1:3000 (DAKO, P0447) in 1\% non-fat dry milk was used in conjunction with COX2 antibody and a polyclonal horseradish peroxidise conjugated goat anti-rabbit immunoglobulin 1:5000 in 1\% nonfat dry milk (DAKO, P0448) was used for IкB- $\alpha$, phospho-P65 and $\mathrm{P} 65$ antibody.

After further TBS-T wash, enhanced chemiluminescent (ECL) reagent (Fisher Scientific, 12316992) was applied to the PVDF membranes for $5 \mathrm{~min}$. Membranes were dried, placed in development cassettes and developed manually onto photographic film in a dark room. Equal loading of proteins was assessed by staining of the PVDF membrane with Napthol Blue Black Reagent (0.1\% napthol blue black, 10\% methanol, $2 \%$ acetic acid) to detect actin protein $(43 \mathrm{kDa})$. Developed films were densitometrically scanned using UMAX PowerLook III (UMAX) and quantification performed with Bio Image Intelligent Quantifier 2 software (Bioimage systems).

\section{Measurement of mRNA Expression}

Following extraction of RNA (as per above), gene expression was assessed via the measurement of mRNA transcripts across a panel of selected genes using RT qPCR arrays (Qiagen, Custom RT2 profiler PCR arrays, 330171). All work was carried out in a ribonuclease free environment with ribonuclease free equipment. 
TABLE 2 | Genes used in RT2 profiler PCR array plates.

\begin{tabular}{ll}
\hline Gene grouping & Gene name \\
\hline $\begin{array}{l}\text { Labor associated genes } \\
\text { Inflammatory Genes }\end{array}$ & $\begin{array}{l}\text { OXTR/MMP 9/ MMP19/ TIMP1/ GJA1/GJB2 } \\
\text { IL1A/L1B/TNFA/IL6/IL8/ICAM1/ SOCS3 /L1R1/ } \\
\text { IL1R2/IL4R/CXCL2/ CXCL1/CXCL6/CCL2 }\end{array}$ \\
NFKB pathway & NFKB1/NFKB2/ RELA/NFKBIA/NFKBIZ \\
Prostaglandin production & PTGER3/PLA2G2A/ PTGES/PTGS2 \\
G protein receptors & GPR37/GPR34/RGS 10 \\
Novel genes & S100A9/ S100A8/STAT1/ FOXO1/ ZEB1/ LILRA5/ \\
Housekeeping genes & SPINK5/FOSB/JUN/TRIB1 \\
& GAPDH/ACTB/B2M
\end{tabular}

Measurement of the RNA content in each sample was undertaken using a nanodrop spectrophotometer (ND-1000, Labtech), with suitable RNA purity considered to be a 260/280 ratio of $>2.1$. $0.5 \mu \mathrm{g}$ of total RNA from each sample was added to the genomic DNA elimination mix from RT2 first strand kit (Qiagen, 330404) reverse transcription was then carried out according the manufacturers' instructions.

cDNA as synthesized from $0.5 \mu \mathrm{g}$ of total RNA from each original sample was added to the SYBR Green Master Mix (Qiagen, 330171). Twenty-five microliters of this final mix was then added to each well of a 96 well-array plate, with each wellcontaining a different primer for a gene of interest or control. The plate was sealed with optical film, centrifuged at 1,000 rpm $(89 \times \mathrm{g})$ for $1 \mathrm{~min}$ before inserting the plate into the PCR cycler (Step One Plus, Applied Biosciences) according to a protocol of enzyme activation hot start at $95^{\circ} \mathrm{C}$ for $10 \mathrm{~min}$, followed by 40 cycles of denaturing at $95^{\circ} \mathrm{C}$ for $15 \mathrm{~s}$ and extension at $60^{\circ} \mathrm{C}$ for $60 \mathrm{~s}$.

Fluorogenic data was collected via the FAM channel and the cycle threshold $(\mathrm{Ct})$ values were calculated by applying a threshold limit that represented the exponential phase of amplification. To ensure comparability of gene expression between different array plates the same threshold limit was applied to all experiments (Ct 0.116). This was calculated as a mean threshold value from the first 6 arrays and corresponded to the exponential phase of the amplification curve for all subsequent experiments.

These array plates were created bespoke for the authors by Qiagen and the genes selected for examination are demonstrated in Table 2. The approach taken to gene selection is described within the results section below.

Analysis of mean $\mathrm{Ct}$ values and quality control were evaluated by exporting mean $\mathrm{Ct}$ values for each gene on the RT2 array plate to the following data analysis website supported by Qiagen: https://dataanalysis.sabiosciences.com/pcr/arrayanalysis.php.

Gene expression was normalized to three reference housekeeping genes $\beta 2$-microglobulin (B2M), GAPDH and $\mathrm{ACTB}$, and results calculated using the $\Delta \Delta \mathrm{C}_{\mathrm{T}}$ method.

For all qPCR gene array experiments raw $\mathrm{Ct}$ values are included in the Supplemental Data 1.

\section{Statistical Analysis}

Prism 7.0 (GraphPad) software was used to perform statistical analysis. For western blotting data statistical analysis was performed on raw optical densitometry values. One or twoway (time/dose) ANOVA with post-hoc corrections were performed to compare differences between groups, as indicated in figure legends. For initial mRNA expression experiments comparing untreated and IL1 $\beta$ treated samples (Figure 8) $P$-values were calculated based on a Student's $t$-test of the replicate $2^{\wedge} \Delta \Delta \mathrm{Ct}$ values of each gene. For subsequent mRNA experiments comparing inhibitor groups (Table 3 and Supplemental Figure 3) one-way ANOVA with Bonferroni posthoc corrections were performed to compare differences between groups. Statistical significance was assumed at $P<0.05$.

For all experimental conditions: each $n$ represents a biological replicate i.e., each $\mathrm{n}$ is a separate experiment using cell cultures grown from myometrial biopsy of a new patient.

\section{RESULTS}

\section{Penetratin CPP Effectively Delivers Fluorescent Cargo to Human Myometrial Cells}

Using the well-characterized Penetratin CPP, we initially investigated whether human myometrial cells were accessible to the CPP-mediated delivery of rhodamine fluorophore.

Figure 1 displays representative confocal microscope images of live uterine smooth muscle cells $1 \mathrm{~h}$ after application of rhodamine fluorescent cargo conjugated to either Penetratin (CPP), Pen-NBD, or to Pen(43-56)-NBD. The delivery of fluorescent cargo was assessed by comparison to that of a rhodamine-conjugated control peptide purported to not have cell penetrating ability $\left[\mathrm{GS}_{4}(\mathrm{GC})\right]$ (40) which can be viewed in Figure 1D.

At 1,3 , and $10 \mu \mathrm{M}$ the rhodamine fluorophore was successfully delivered internal to the cells within $60 \mathrm{~min}$ of application, with an increase in intensity of uptake with increasing concentration (Figures 1A-C). By comparison the inert peptide $\mathrm{GS}_{4}(\mathrm{GC})$ at $10 \mu \mathrm{M}$ did not appreciably deliver the rhodamine fluorophore after $60 \mathrm{~min}$ (Figure 1D). This indicates the ability of CPPs to deliver cargo to human myometrial cells.

Following $60 \mathrm{~min}$ of cellular application, the CPP-fluorophore conjugates (Figure 1A) and also the CPP-cargo-fluorophore conjugates (Figures 1B,C) largely demonstrated a punctate pattern of labeling indicative of endosomic labeling. This is best demonstrated in the image of Rhodamine-Pen-NBD at $10 \mu \mathrm{M}$ (Row B, third picture from left). It can be noted that this punctate labeling forms larger accumulations with the use of Pen(43-56)NBD (Figure 1C), this may be attributed to alteration of the $\mathrm{CPP}$-cargo amino acid structure, a phenomenon referred to in the discussion below.

\section{The CPP-Cargo Conjugate Pen-NBD Inhibits Cytokine-Activated COX2 Expression}

Initial experiments determined that CPP use was not toxic to myometrial cells (Supplementary Figure 4). Penetratin conjugated to the NBD peptide (Pen-NBD) was applied to myometrial cell cultures in increasing concentrations $1 \mathrm{~h}$ prior to addition of $10 \mathrm{ng} / \mathrm{ml}$ of IL1 $\beta$. As demonstrated 


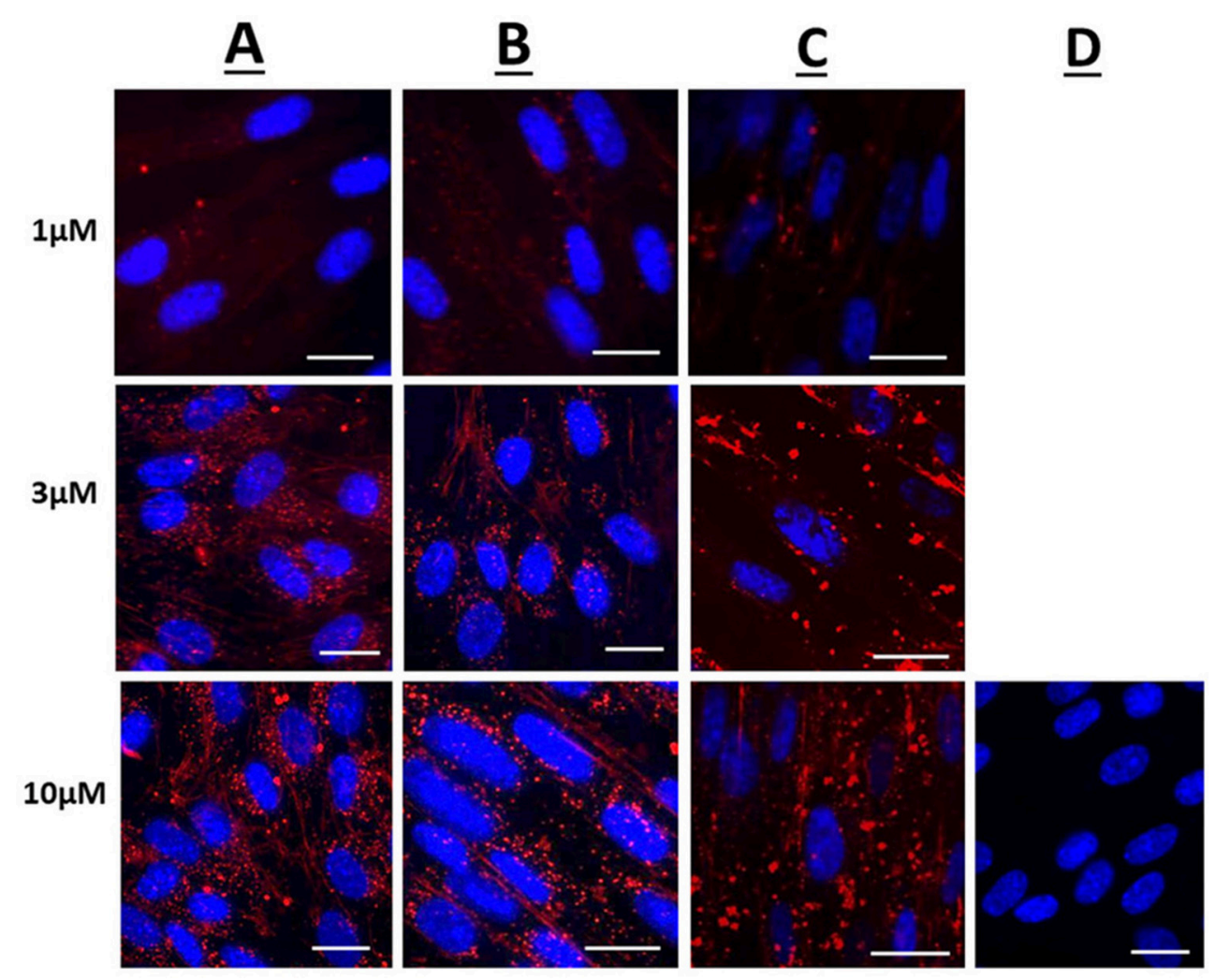

FIGURE 1 | Confocal microscopy images of live human uterine smooth muscle cells following application of rhodamine-conjugated CPPs or CPP-cargo combinations. Images captured 60 min following addition of either 1, 3, or $10 \mu \mathrm{M}$ concentrations of (A) Rhodamine-Penetratin, (B) Rhodamine-Pen-NBD, or (C) Rhodamine-Pen (43-56)-NBD. (D) Displays cells imaged 60 min following addition of $10 \mu \mathrm{M}$ control peptide Rhodamine - GS4 (GC). Scale bars $20 \mu \mathrm{m}$. Cells are maintained in serum deprived media within a temperature-controlled chamber $\left(37^{\circ} \mathrm{C}, 5 \% \mathrm{CO} 2\right)$. To demonstrate intra-cellularity of uptake, images are taken from the center of a Z-stack of 3-10 slices $(0.54 \mu \mathrm{m}$ apart) intended to capture the full depth of the cell. Images are representative of 3 independent experiments.

in the Western blot portrayed in Figure 2: in the absence of inhibitor (IL1 $\beta$ alone) induction of the protein enzyme COX2 is evident at $2 \mathrm{~h}$ and continues to increase at $4 \mathrm{~h}$ following cytokine application. Pre-incubation of 50 and $100 \mu \mathrm{M}$ Pen-NBD led to significant inhibition of these cytokine-stimulated increases in COX2 protein signal at both $2 \mathrm{~h}(50 \mu \mathrm{M} p=0.01 ; 100 \mu \mathrm{M}$ $p=0.003)$ and $4 \mathrm{~h}(50 \mu \mathrm{M} p=0.049 ; 100 \mu \mathrm{M} p=0.0003)$.

Control experiments were performed to test the specificity of COX2 responses to the NBD peptide. The inhibitory effect of Pen-NBD on IL1 $\beta$-induced COX2 protein expression was compared with a Penetratin-conjugated mutant version of the NBD peptide: Pen-NBD (Mut), and NBD peptide alone (without conjugation to $\mathrm{CPP}$ ). Figure 3 displays a representative Western blot with scatter graphs demonstrating three independent experiments to compare COX2 protein responses to IL1 $\beta$ following the pre-incubation with either Pen-NBD mutant or wild type peptide. It demonstrates that the mutant peptide does not diminish IL1 $\beta$-stimulated COX2 induction when used at identical concentrations to the wild type peptide.

Application of non-conjugated NBD peptide had no inhibitory effect on cytokine-stimulated COX2 protein increases, nor did application of CPP alone (Supplementary Figure 1), thus indicating the requirement of $\mathrm{CPP}$-conjugation to NBD for the inhibitory effect to be evident.

\section{In Human Myometrial Cells Pen-NBD Does Not Prevent the Cytokine-Stimulated Degradation of $I \kappa B \alpha$ but Does Diminish Phosphorylation of P65 Following IL1 $\beta$ Exposure}

It was important to assess the effect of CPP-based inhibition on protein expression changes within the canonical NFKB pathway subsequent to IL1 $\beta$ stimulation. Within myometrial cells, increases in the phosphorylated form of the NFкB subunit p65 protein are observed at $15 \mathrm{~min}$ due to the action of the activated IKK complex (Supplementary Figure 2), these responses gradually diminish over the tested $4 \mathrm{~h}$ time frame but do not return to normal, suggestive of increased background $\mathrm{NF} \kappa \mathrm{B}$ activity following cytokine stimulation in human uterine cells over the time frame examined. Additionally, within $15 \mathrm{~min}$ of exposure to IL1 $\beta$, there is both phosphorylation of the inhibitory $\mathrm{I} \kappa \mathrm{B} \alpha$ protein and degradation of its native form with full return of the native form of this inhibitory protein occurring between $60 \mathrm{~min}$ and $2 \mathrm{~h}$.

At all concentrations tested, Pen-NBD did not prevent the cytokine-induced degradation of I $\mathrm{B} \alpha$ (Figure 4A). However, a significant reduction of P65 protein phosphorylation $15 \mathrm{~min}$ following application of IL1 $\beta$ was 

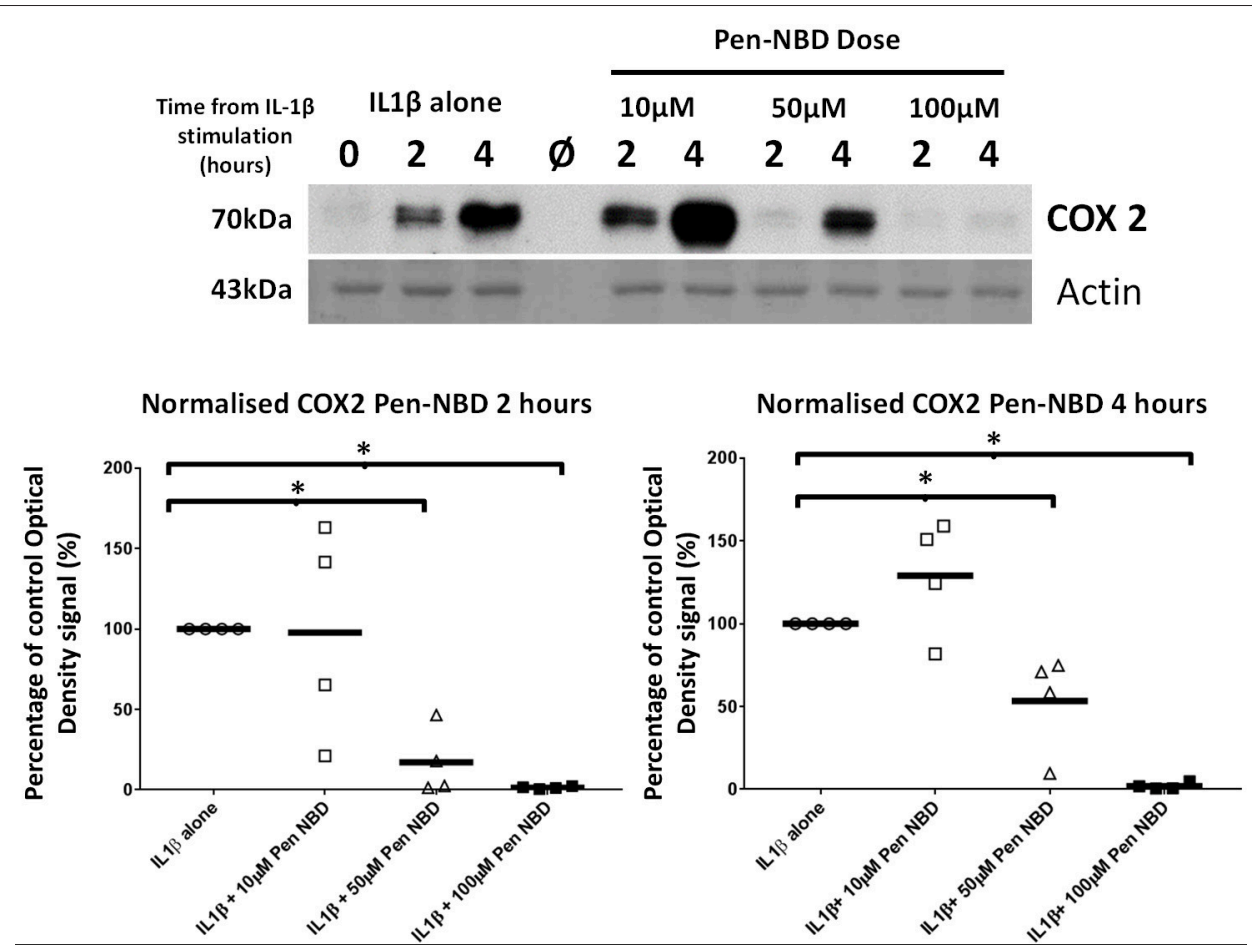

FIGURE 2 | Effect of Pen-NBD peptide on IL1 $\beta$-stimulated COX2 protein increases. (Upper) Representative Western blot demonstrating COX2 protein increase at 2 and $4 \mathrm{~h}$ following application of $10 \mathrm{ng} / \mathrm{ml} \mathrm{IL} 1 \beta$ alone or with pre-incubation for $1 \mathrm{~h}$ with indicated concentrations of Pen-NBD peptide prior to IL1 $\beta$ addition. Actin expression displayed as loading control. $\varnothing=$ no protein loaded. (Lower) Scatter plot demonstrating optical density values of COX2 protein signal at 2 and $4 \mathrm{~h}$ time points comparing IL $1 \beta$ alone or Pen-NBD plus IL $1 \beta$ experiments. Data presented has been normalized to control signal to demonstrate inhibitory effect. *Significant difference from raw optical density values between IL1 $\beta$ alone and IL1 $\beta$ plus Pen-NBD groups ( $n=4$, one-way ANOVA with Bonferroni post-hoc correction).

observed with the use of $100 \mu \mathrm{M}$ Pen-NBD $(p=0.025)$ (Figure 4B).

\section{The NBD Peptide Conjugated to the} Truncated Penetratin Vector Pen(43-56) Is Capable of COX2 Inhibition but Is Less Efficacious Than Pen-NBD and Does Not Influence IKK-Dependent Protein

\section{Alterations Within the NFKB Pathway}

To test the effect of alterations of the CPP vector on the efficacy of NBD cargo protein-protein interactions, experiments were performed using the NBD peptide conjugated to a truncated arrangement of the CPP Penetratin, to form Pen(43-56)-NBD. This CPP-peptide fusion has previously demonstrated ability to block IL1 $\beta$-induced NFKB activity in HeLa cell lines (38), but has not been examined previously in a gestational cell setting.

Applied to human myometrial cells $100 \mu \mathrm{M}$ Pen (43-56)NBD was able to inhibit IL1B-induced COX2 protein increases at $4 \mathrm{~h}(p=0.0045)$ (Figure 5A). Such inhibition was not seen with the use of lower doses (data not shown). This CPP-cargo conjugation did not inhibit I $\mathrm{B} \alpha$ protein degradation or P65 protein phosphorylation (Figures 5B,C).
The Small Molecule Inhibitor Sc514 Exerts Inhibitory Effect on COX2 Protein Induction Via Alteration of IKK-Dependent Events Within the NFKB Pathway

Sc514 at $50 \mu \mathrm{M}$ concentration was applied to myometrial cells $1 \mathrm{~h}$ prior to IL1 $\beta$ stimulation. Significant reduction in COX2 protein expression with the use of this inhibitor was observed at $4 \mathrm{~h}$ $(p=0.001)$. IL1 $\beta$-induced degradation of Iк $\mathrm{B} \alpha$ was inhibited $(p=0.009)$ as was the phosphorylation of P65 protein $(p=0.001)$ (Figures 6A-C).

\section{IL1 $\beta$ Promotes Inflammation- and Labor-Related Gene Expression Changes in Human Myometrial Cells}

To further demonstrate the response of myometrial cells to inflammatory stimulation and to compare the ability of CPP based and small molecule inhibitory strategies to these responses a bespoke q-PCR array panel of 42 genes was used. The genes examined in this study are listed in Table 2 . The approach to gene selection for this panel was multifactorial: a number of genes encoding for proteins associated with the physiological events of uterine contraction, cervical dilation and membrane rupture that occur during human labor, termed labor associated genes, were selected (41); also, for comparison, a collection of 
genes encoding for G-proteins involved in maintaining uterine quiescence (42). A number of pro inflammatory genes, including genes encoding for proteins in the $\mathrm{NF \kappa B}$ pathway (16), and genes involved in the production of prostaglandins (18) were chosen to aid understanding of the potential mechanism of action of inhibitors used in this study. A selection of novel genes that demonstrate altered expression in the presence of human labor were also included in the array (43).

Across eight independent samples a series of gene expression changes were observed in myometrial cells $4 \mathrm{~h}$ following exposure to $10 \mathrm{ng} / \mathrm{ml} \mathrm{IL1} \beta$. These changes included genes involved in human labor, inflammatory processes, NFKB signaling, and prostaglandin expression as demonstrated in the heat map displayed in Figure 7.

The volcano plot presented in Figure 8 demonstrates those genes exhibiting significant expression changes with greater than 2 -fold difference between IL1 $\beta$-treated and untreated samples. The genes displaying the largest expression changes within the panel were inflammatory cytokines/chemokines and genes associated with the NFKB family.
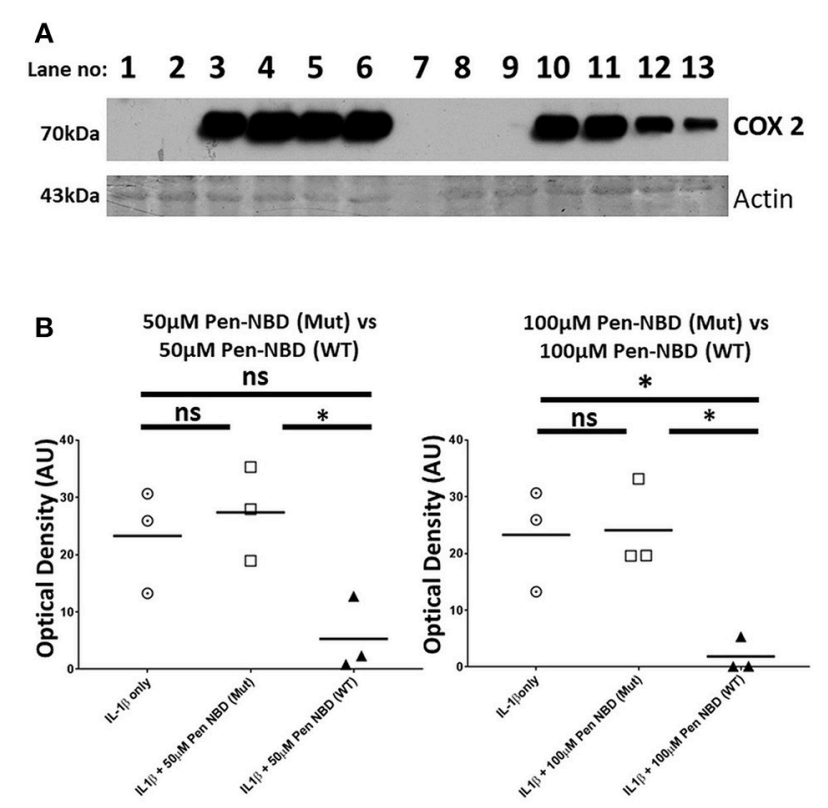

FIGURE 3 | Comparison of effect of Pen-NBD mutant (Mut) peptide with Pen-NBD wild type (WT) on IL1 $\beta$-stimulated COX2 protein responses. (A) Representative Western blot demonstrating COX2 protein changes at indicated time points. Lanes $1,2,8$, and 9 display protein expression with no agonist addition. Lanes 3 and 10 display protein expression with addition of $10 \mathrm{ng} / \mathrm{ml} \mathrm{IL1} \beta$ alone. Lanes 4 and 11 display protein expression with DMSO vehicle plus IL1 $\beta$. Lanes 5 and 6 display protein expression with Pen-NBD (Mut) at indicated concentrations plus IL $1 \beta$ and lanes 12 and 13 display Pen-NBD (WT) at indicated concentrations plus IL $1 \beta$. Actin expression displayed as loading control. Lane 7 -no protein addition. (B) Scatter plots demonstrating comparison of optical density values of COX2 protein signal between IL1 $\beta$ only, IL $1 \beta$ plus Pen-NBD (Mut), or IL1 $\beta$ plus Pen-NBD (WT) at indicated concentrations. ${ }^{*}$ Significant difference from raw optical density values between IL $1 \beta$ only and IL $1 \beta$ plus Pen-NBD groups ( $n=3$, one-way ANOVA with Bonferroni's post-hoc correction).

\section{CPP-Conjugated and Small Molecule Inhibitors of NFKB Dampen the IL1 $\beta$-Stimulated Expression of Different Groups of Genes in Myometrial Cells}

Having identified expression changes within the gene array panel following stimulation by IL1 $\beta$, it was important to examine how this expression pattern would be altered using a CPP-based or small molecule inhibitory strategy. It was also of interest to observe how alterations to vector structure may affect the efficacy of CPP-cargo inhibition.

Application of either Pen-NBD, Pen(43-56)-NBD or Sc514, $1 \mathrm{~h}$ prior to cytokine exposure, significantly inhibited the IL1 $\beta$-stimulated expression of many genes within the array panel. The pattern of inhibition can be observed in both Table 3 and the scatter graphs demonstrating fold expression changes presented within the Supplementary Data (Supplementary Figures 3A-E).

Of note, Pen-NBD and Sc514 had broad and similar antiinflammatory effects and both approaches significantly inhibited $\mathrm{NF} \mathrm{B}$ family gene expression and prostaglandin pathway expression. For the labor associated genes: Pen-NBD, but not Sc514, inhibited the cytokine-induced expression of the oxytocin

TABLE 3 | Effect of CPP-based or small molecule inhibitors on IL1 $\beta$ induced gene expression changes in myometrial cells.

\begin{tabular}{|c|c|c|c|c|}
\hline \multirow[t]{2}{*}{ Gene group } & \multirow[t]{2}{*}{ Gene name } & \multicolumn{3}{|c|}{ Inhibitor } \\
\hline & & Pen-NBD & Pen(43-56)-NBD & Sc514 \\
\hline \multirow{2}{*}{$\begin{array}{l}\text { Labor } \\
\text { associated } \\
\text { genes }\end{array}$} & OXTR & $\downarrow(p=0.01)$ & - & - \\
\hline & MMP9 & - & - & $\downarrow(p=0.01)$ \\
\hline \multirow{6}{*}{$\begin{array}{l}\text { Inflammatory } \\
\text { cytokines }\end{array}$} & IL1A & $\downarrow(p \leq 0.0001)$ & $\downarrow(p=0.003)$ & $\downarrow(p=0.001)$ \\
\hline & IL1B & $\downarrow(p \leq 0.0001)$ & $\downarrow(p=0.034)$ & $\downarrow(p=0.004)$ \\
\hline & TNF & - & - & $\downarrow(p=0.0004)$ \\
\hline & IL16 & $\downarrow(p=0.016)$ & - & $\downarrow(p=0.0004)$ \\
\hline & IL18 & $\downarrow(p=0.023)$ & - & $\downarrow(p=0.0007)$ \\
\hline & ICAM1 & - & - & $\downarrow(p=0.04)$ \\
\hline \multirow{3}{*}{$\begin{array}{l}\text { Inflammatory } \\
\text { chemokines }\end{array}$} & CXCL2 & - & - & $\downarrow(p=0.0013)$ \\
\hline & CXCL6 & $\downarrow(p \leq 0.0001)$ & $\downarrow(p \leq 0.0001)$ & - \\
\hline & CCL2 & $\downarrow(p \leq 0.0001)$ & $\downarrow(p=0.0003)$ & $\downarrow(p=0.01)$ \\
\hline \multirow{4}{*}{$\begin{array}{l}\text { NFKB family } \\
\text { genes }\end{array}$} & NFKB1 & $\downarrow(p=0.0039)$ & - & $\downarrow(p=0.001)$ \\
\hline & NFKB2 & $\downarrow(p=0.01)$ & - & $\downarrow(p=0.045)$ \\
\hline & RELA & $\downarrow(p=0.0049)$ & - & - \\
\hline & NFKBIZ & - & - & $\downarrow(p=0.008)$ \\
\hline \multirow{2}{*}{$\begin{array}{l}\text { Prostaglandin } \\
\text { pathway } \\
\text { genes }\end{array}$} & PTGES & $\downarrow(p \leq 0.0001)$ & $\downarrow(p=0.003)$ & - \\
\hline & cox2 & $\downarrow(p=0.0007)$ & - & $\downarrow(p=0.01)$ \\
\hline
\end{tabular}

Taken from the 42 gene array, the table demonstrates only the genes with significantly altered expression patterns between control (IL1 $\beta$ alone) or treatment (IL1 $\beta$ plus either $100 \mu M$ Pen-NBD/100 $\mu M$ Pen(43-56)-NBD/50 $\mu$ M Sc514) groups. $\downarrow$ indicates significantly altered gene expression in presence of inhibitor compared with IL $1 \beta$ alone. indicates no significant change between groups. Scatter graphs demonstrating changes for each gene displayed can be found in Supplementary Figure 3. 


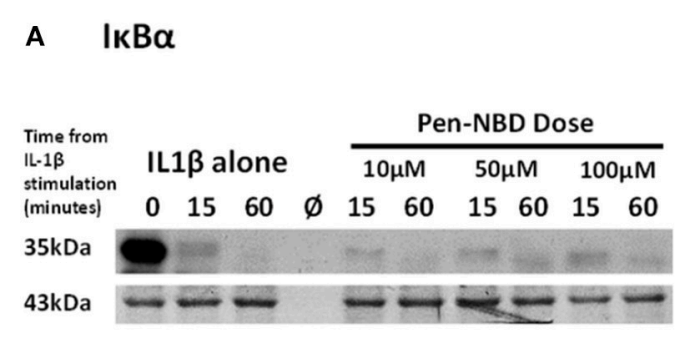

$$
\text { B }
$$
p-P65

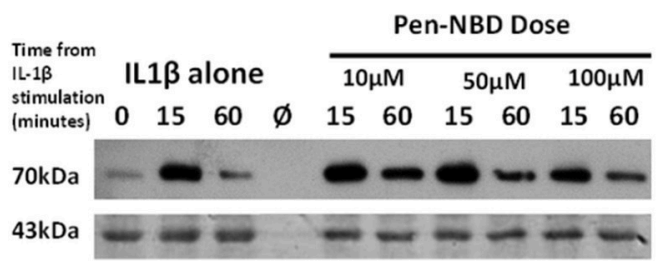

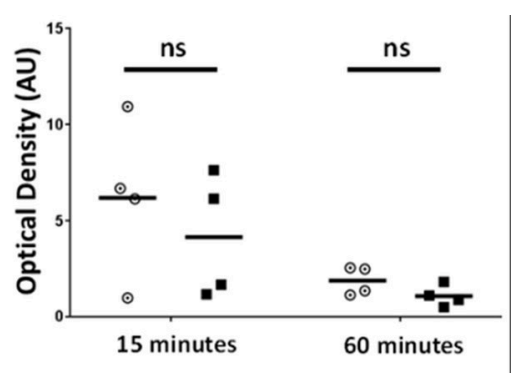

$\odot$ IL1 $\beta$ alone

- IL1 $\beta$ plus $100 \mu \mathrm{M}$ Pen-NBD

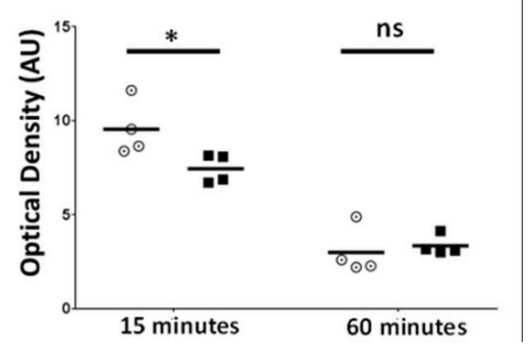

FIGURE 4 | Effect of Pen-NBD on the cytokine-induced degradation of $I_{\kappa} B \alpha$ protein and phosphorylation of P65 protein. (Left) Representative Western blots demonstrating responses of (A) lкB $\alpha$ protein and (B) phosphorylated P65 protein at 15 and 60 min following application of 10 ng/ml IL1 $\beta$ either alone or following pre-incubation for $1 \mathrm{~h}$ with indicated concentration of Pen-NBD peptide prior to IL $1 \beta$ addition. Actin expression displayed as loading control. $\varnothing=$ no protein loaded. (Right) Scatter plots demonstrating raw optical density values of (A) $\mathrm{I}_{\kappa} \mathrm{B} \alpha$ protein and (B) phosphorylated P65 protein signal at 15 and 60 min time points comparing IL $1 \beta$ alone or $100 \mu \mathrm{M}$ Pen-NBD plus IL1 $\beta$ experiments. *Significant difference from raw optical density values between IL $1 \beta$ alone or $100 \mu M$ Pen-NBD plus IL $1 \beta$ groups ( $n=4$, two-way ANOVA with Sidak's post-hoc correction).

receptor gene OXTR. In contrast, Sc514, but not Pen-NBD inhibited the gene encoding for the matrix metalloproteinase MMP 9.

Use of the truncated CPP vector Pen (43-56) combined with NBD demonstrated much more limited ability to inhibit cytokine induced changes in gene expression and did not affect the expression of NFKB pathway, prostaglandin, or labor associated genes. This further demonstrates the importance of appropriate vector selection for any treatment strategy involving CPP-Cargo delivery.

\section{DISCUSSION}

Within the reproductive literature a substantial body of evidence places intracellular NFKB activation centrally amongst the molecular pathways associated with inflammatory preterm birth $(12,44)$. With this in mind, a novel approach was adopted here to investigate inhibition of inflammatory signaling in human myometrial cells. We compared two classes of agent targeting the IKK complex upstream within the NFKB pathway, aiming to diminish NFкB-dependent uterine cell inflammatory responses: CPP's conjugated to the NBD peptide and the small molecule inhibitor Sc514.

The CPP-cargo construct, Pen-NBD, was used with the aim of avoiding the need for receptor-ligand interactions on the cellular membrane and thus to precisely deliver bioactive cargo to the intended intracellular target. COX2 is an inducible ratelimiting enzyme in the production of prostaglandins in uterine cells. Prostaglandins are vital mediators in the induction of laboring processes and potent uterotonins that can initiate uterine contractions therefore the demonstration in this study that CPP mediated delivery of the NBD peptide inhibits the IL1 $\beta$ induced expression of COX2 is of importance. A previous study examining the effect of the NBD peptide in a sheep model found it to be broadly ineffective at dampening inflammatory responses in sheep fetal membranes at $10 \mu \mathrm{M}$ (45). This work supports that conclusion, but also emphasizes the importance of basic testing of novel compounds over a broad time and concentration range as inhibition of inflammatory responses was only observed at concentrations greater than or equal to $50 \mu \mathrm{M}$ within the experiments presented here.

Hundreds of CPP sequences have now been discovered that could be linked to the NBD peptide. Even amongst wellcharacterized CPPs such as Penetratin or TAT differences exist within the literature as to the precise amino acid structure used (46), and differences in the position of key amino acid residues or charged groups within the CPP vector-cargo conjugate can alter the efficiency of delivery, with the possibility that this may in turn affect the biological effectiveness and targeting of the peptide $(47,48)$. In order to explore this effect of vector alteration on the overall efficacy of CPP-cargo combination, this study also examined NBD delivery and biological effect when combined to a truncated form of Penetratin CPP (Pen 43-56) that has 


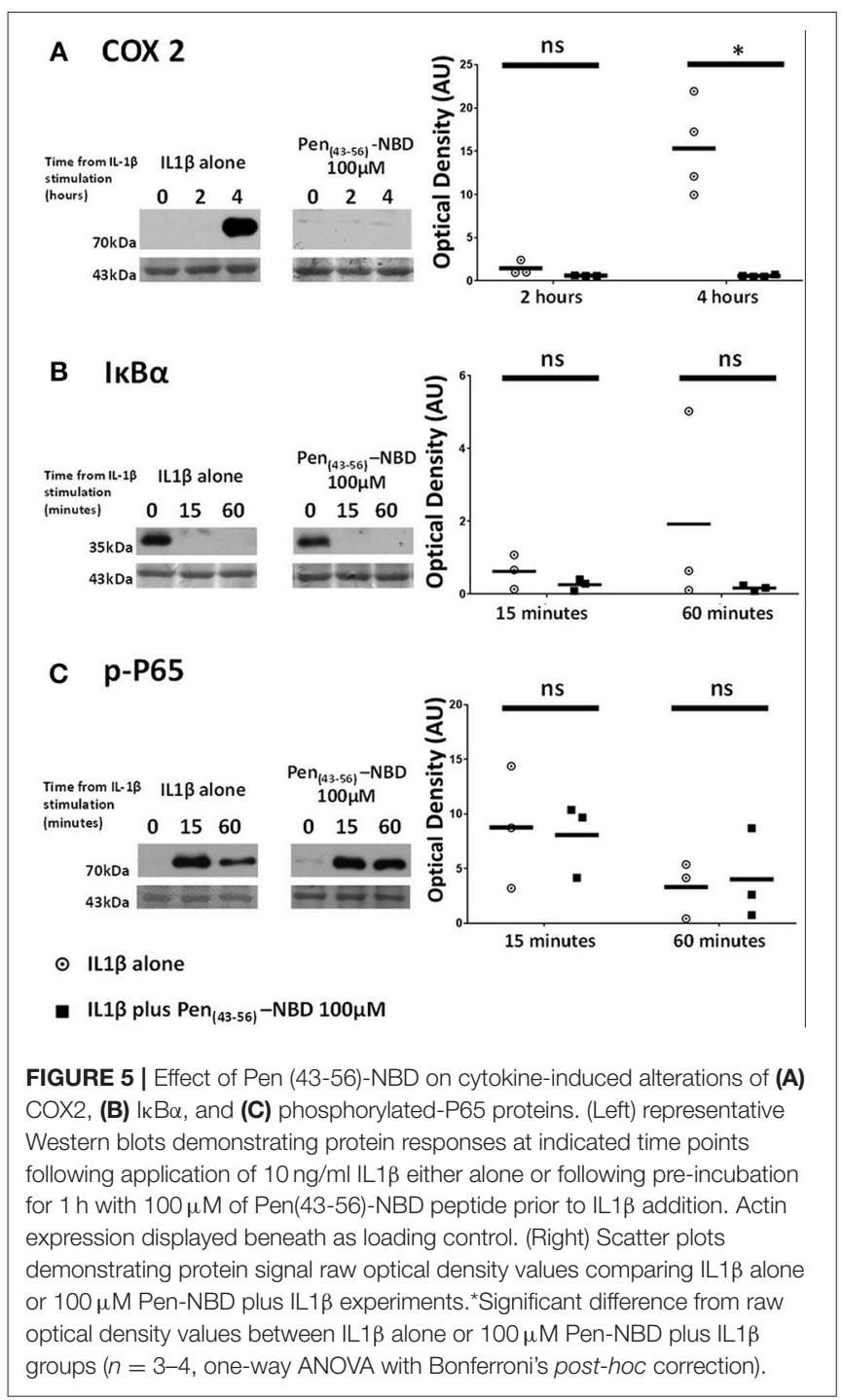

two lysine amino acid residues removed from the C-terminal end of the peptide (49). Conjugated to rhodamine Pen(43-56)NBD demonstrated ability to enter myometrial cells within a similar time-dose range to Pen-NBD, but it was notable that the intracellular appearances of fluorophore were larger, possibly due to a clumping phenomenon secondary to altered charge and $\mathrm{pH}$ properties of the truncated CPP-cargo construct. Pen(43-56)NBD also required increased concentrations to inhibit cytokineinduced increases in COX2 protein when compared to the nontruncated form and did not prevent alterations of NFKB pathway proteins downstream of IKK complex activation. Additionally, pen(53-46)-NBD was less effective in attenuating IL1 $\beta$-induced gene expression changes compared with Pen-NBD peptide. Thus, careful selection of the CPP vector used, consideration of vectorcargo interactions and investigation of mechanisms of action are vital considerations for work involving peptide-based therapies.

The small molecule inhibitor Sc514 was chosen to compare this CPP-based therapeutic approach as it has a putatively very similar mechanism of action focussed on interaction with IKK

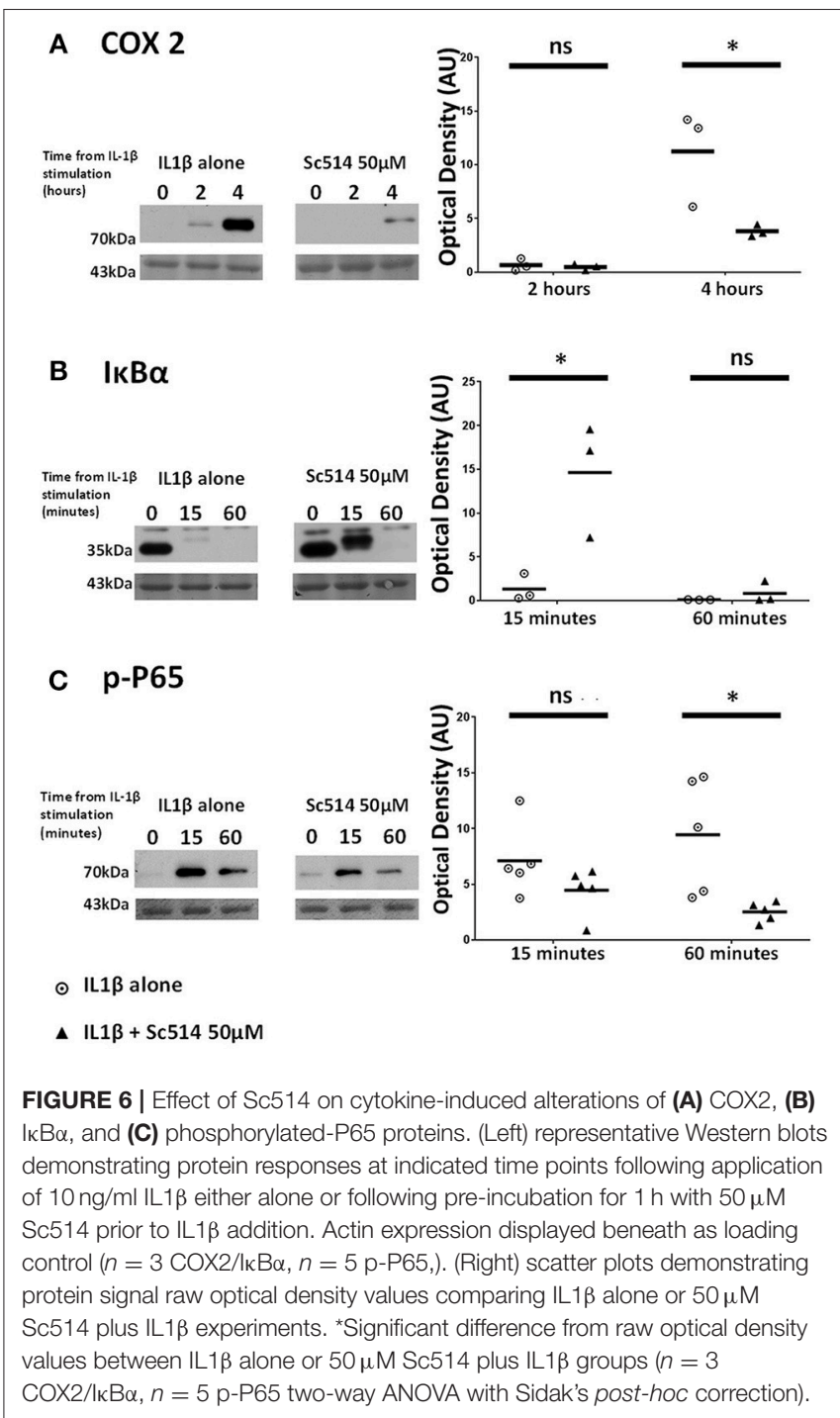

complex to prevent its activation within the canonical NFKB pathway. As with Pen-NBD, Sc514 demonstrated ability to inhibit cytokine-induced COX2 production and p65 phosphorylation. However, whereas Pen-NBD did not prevent the IL1 $\beta$-dependent degradation of $\mathrm{I} \kappa \mathrm{B} \alpha, \mathrm{Sc} 514$ demonstrated ability to inhibit degradation of this protein. Therefore, the ability of Sc514 to prevent the degradation of this protein in comparison to the NBD cargo may relate to subtle differences in mechanism of action. The IKK $\beta$ subunit is primarily responsible for the phosphorylation of $\mathrm{I} \kappa \mathrm{B} \alpha$ from which subsequent degradation occurs and Sc514 has previously demonstrated specificity toward IKK $\beta$ inhibition (35), whereas NBD peptide blocks association between NEMO and the other subunit portions of the IKK complex (29). Thus, the inability of Pen-NBD to prevent ІкB $\alpha$ degradation in myometrial cells could either be due to an incapacity to dampen IKK $\beta$-specific responses or to the actions of alternative IKK complexes within the cell that can lack Nemo Binding Domain (50). 


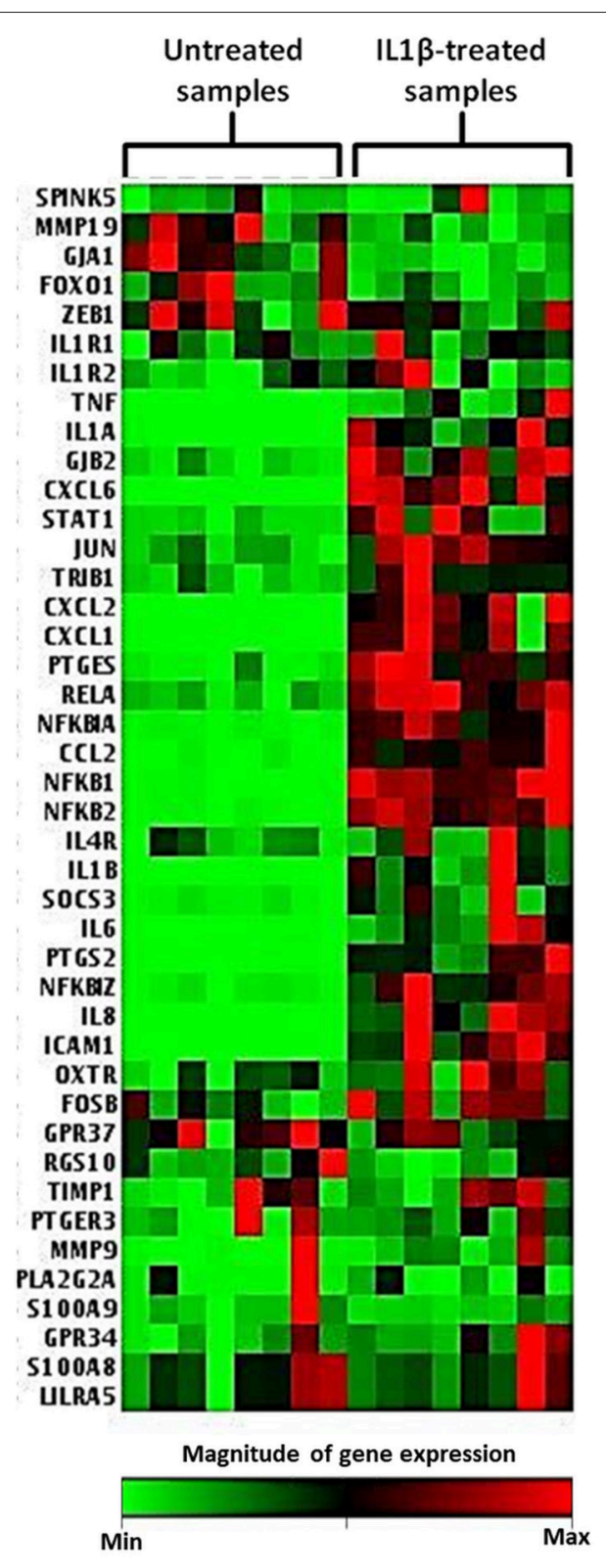

FIGURE 7 | Heat map demonstrating myometrial cell gene array expression in response to IL $1 \beta$ cytokine stimulation. The heat map displays gene expression changes from an array of $42 \mathrm{GOI}$ for untreated and IL $1 \beta$ treated samples from eight biological replicates. Highly expressed genes are displayed as shades of red and minimally expressed genes are shown as shades of green $(n=8)$.

To examine the wider anti-inflammatory effects of both CPPcargo and small molecular inhibitory approaches the expression of a bespoke array of genes was used to examine myometrial gene expression changes in response to cytokine stimulation, and, subsequently, the effect of the inhibitory approaches to dampen such responses. Application of IL1 $\beta$ to myometrial cells produced many gene expression changes that have been previously observed in comparisons between human laboring and non-laboring samples including upregulation of $\mathrm{NF} \mathrm{B}$ pathway components, cytokines such as IL6 and IL8 and genes with specific associations with human labor such as PTGS2 and $\operatorname{OXTR}(51,52)$.

Sc514 and Pen-NBD had similar anti-inflammatory effects dampening the cytokine-provoked transcription of NFKB family genes and key cytokines such as IL6 and IL8. There were interesting variations in this effect with Pen-NBD demonstrating inhibition of OXTR, the gene transcribing for oxytocin receptor protein; whereas Sc514 inhibited the cytokine-induced upregulation of the matrix metalloproteinase enzyme gene MMP 9. Such variations suggest that with future work to clarify the detailed mechanistic processes behind the varied presentations of preterm birth, different inhibitory approaches could be taken dependent on individual biological situations. It also gives rise to the possibility that in situations where a broad insult is responsible for the onset of preterm birth, more than one agent may be required to prevent this outcome.

\section{LIMITATIONS}

A consistent limitation of fundamental biological studies investigating several outcomes of multiple interventions when using primary sourced human material is tissue availability. This can be further exacerbated when studies refrain from using cells at high passage $(>4)$ to minimize potential deviation from original cellular phenotype. Within such practical and temporal constraints, the final numbers used in some experiments within this study are low; however, the authors feel this does not detract from the innovative nature of the study, and offers incentive for more detailed investigation of the uses of CPP based therapies and Sc514 as inflammatory and potentially contractile inhibitors for use in the field of pregnancy research.

\section{CONCLUSION}

Due to the shortage of candidate agents aimed at the prevention of preterm birth available for clinical testing, a number of approaches have been investigated with the intention of dampening inflammatory-mediated signaling in uterine cells (53, 54). However, most of these, outside of anti-infection strategies, rely upon inhibiting plasmalemmal receptor engagement with cognate ligands. This study presents a novel approach to addressing this problem by establishing that a biologically active cargo, intracellularly delivered by a CPP, can inhibit inflammation-related signaling in human myometrial cells in a similar manner to that of the potent cell-permeable small molecule inhibitor Sc514.

CPPs have the potential to deliver a diverse range of cargo to cells thus the proof of concept demonstrated here that CPP-cargo constructs enter human uterine smooth muscle cells and dampen inflammatory pathways in a targeted fashion is encouraging for the further pursuit of strategies involving varied CPP-cargo constructs that could include targeting alternative inflammatory pathways associated with preterm birth such as MAP kinase and AP1 $(10,11)$. It is well-established that many proteinprotein interactions are classed as non-druggable and cannot be inhibited with small molecule drugs or large proteins and this 


\section{Fold regulation of IL1 $\beta$ treated vs untreated samples}

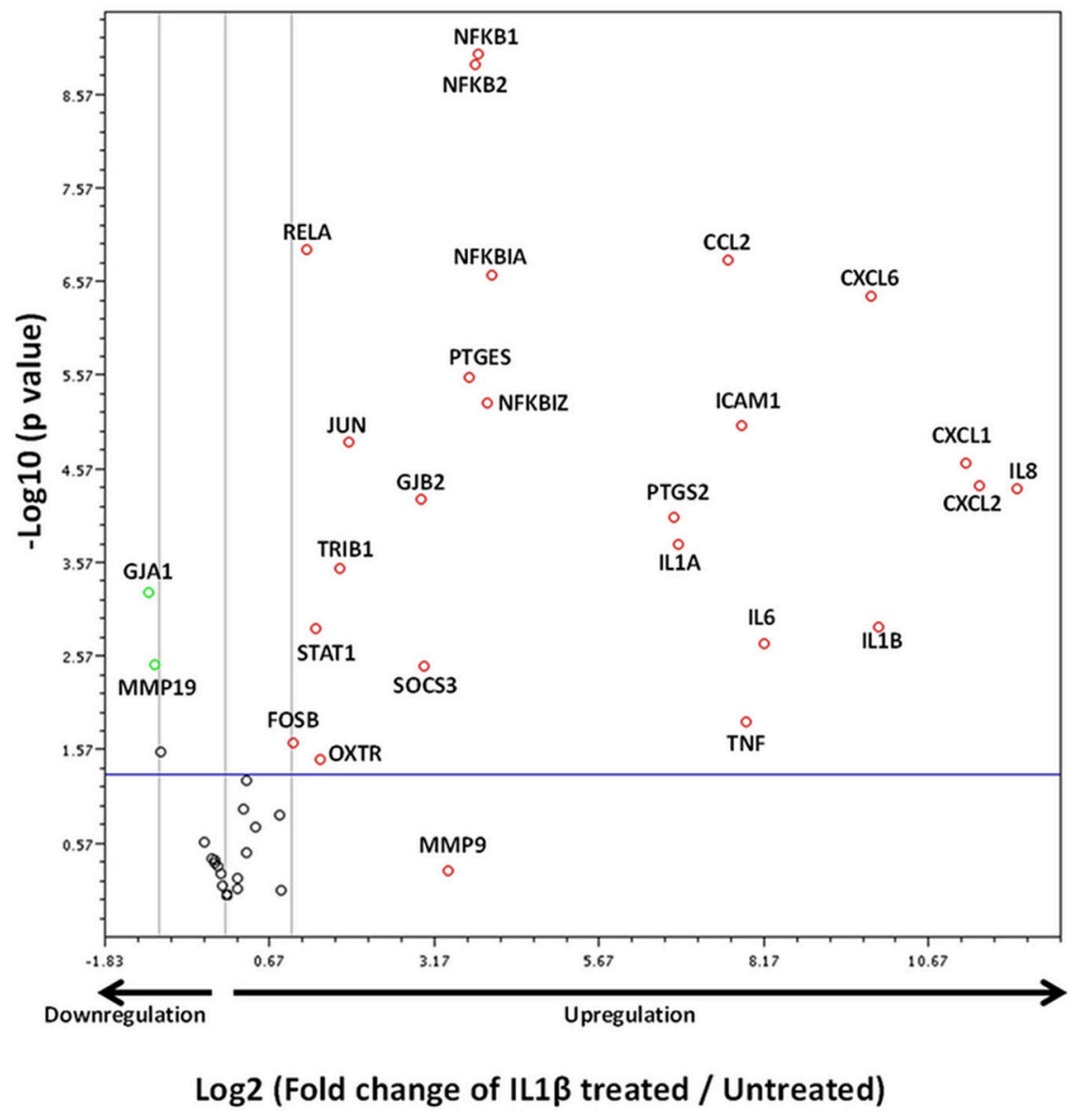

FIGURE 8 | Volcano plot demonstrating gene expression changes in myometrial cells following IL $1 \beta$ exposure. X axis shows fold regulation changes between IL $1 \beta$ treated and untreated samples $4 \mathrm{~h}$ following cytokine addition. $Y$ axis is the inverse of the $\mathrm{p}$ value generated for each gene of interest (GOI) via students $T$-test. All genes with $>2$ fold difference between IL1 $\beta$ treated and untreated samples are labeled on the figure. Upregulated genes are presented as red circles, downregulated genes are green circles and genes demonstrating no change are black circles. Genes above the blue horizontal line represent significant expression changes between IL1 $\beta$ and untreated samples (Student's $t$-test of the replicate $2^{\wedge} \Delta \Delta$ Ct values). Data is summation of experiments from eight biological replicates $(n=8)$.

offers an opportunity for investigating more peptide therapeutics delivered by CPPs.

Although further extensive preclinical testing of these therapeutic strategies is required to establish safety and efficacy over a broad concentration range; the authors envisage the future usage of such agents in an acute setting for pregnant patients presenting with the clinical phenotype of regular contractions before 37 weeks of completed gestation with the intention of both delaying birth to reduce the impact of prematurity on the fetus, and ameliorating the effect of inflammatory insult to both mother and fetus. Treatment delivery could be either through local application to gestational tissues via vaginal pessary; or techniques are evolving quickly for tissue and/or cell-specific delivery of biologically active mediators, including those directed toward uteroplacental environments $(55,56)$, enabling the consideration of systemic usage. Thus, there is much promise for extending in the near future the use of Pen-NBD, other CPP-cargo conjugates and Sc514 to preclinical models of preterm birth.

\section{AUTHOR CONTRIBUTIONS}

LG produced data through experimentation and analyzed and presented data, he also wrote the manuscript and finalized the final paper for submission. JT produced data through experimentation and analyzed and presented data. W-CT provided assistance and advice regarding the use of Sc514. AJ and his group provided collaborative supervision for the use of cell penetrating peptides and live cell microscopy and edited the manuscript. SR provided clinical supervision and oversight throughout the research project, helped facilitate the collection and use of human samples and edited the manuscript. MT oversaw and provided supervision for the whole project and in depth editing and direction for the manuscript. 


\section{FUNDING}

LG was supported by a Well-being of Women Research Training Fellowship (RTF 376).

\section{ACKNOWLEDGMENTS}

LG would like to acknowledge the advice and expert assistance in confocal microscopy he received from Michele Sweeney and Ed Sayers and also the shared experiences of using the NBD peptide derived from conversations with Noura Eissa. The authors

\section{REFERENCES}

1. Blencowe H, Cousens S, Chou D, Oestergaard M, Say LA, Moller B, et al. Born Too Soon: The global epidemiology of 15 million preterm births. Reprod Health (2013) 10(Suppl. 1): S2. doi: 10.1186/1742-4755-10-S1-S2

2. Costeloe KL, Hennessy EM, Haider S, Stacey F, Marlow N, Draper ES. Short term outcomes after extreme preterm birth in England: comparison of two birth cohorts in 1995 and 2006 (the EPICure studies). BMJ (2012) 345:e7976. doi: 10.1136/bmj.e7976

3. Romero R, Espinoza J, Kusanovic JP, Gotsch F, Hassan S, Erez O, et al. The preterm parturition syndrome. BJOG (2006) 113 (Suppl. 3):17-42. doi: 10.1111/j.1471-0528.2006.01120.x

4. Thomson A, Telfer J, Young A, Campbell S, Stewart C, Cameron I, et al. Leukocytes infiltrate the myometrium during human parturtion: further evidence that labour is an inflammatory process. Hum Reprod. (1999) 14:229236. doi: 10.1093/humrep/15.1.229

5. Osman I, Young A, Ledingham MA, Thomson AJ, Jordan F, Greer IA, Norman JE. Leukocyte density and pro-inflammatory cytokine expression in human fetal membranes, decidua, cervix and myometrium before and during labour at term. Mol. Hum. Reprod. (2003) 9:41-5. doi: 10.1093/molehr/gag001

6. Gomez-Lopez N, Estrada-Gutierrez G, Jimenez-Zamudio L, Vega-Sanchez $\mathrm{R}$, Vadillo-Ortega F. Fetal membranes exhibit selective leukocyte chemotaxic activity during human labor. J Reprod Immunol. (2009) 80:122-31. doi: 10.1016/j.jri.2009.01.002

7. Mitchell BF, Taggart MJ. Are animal models relevant to key aspects of human parturition? Am J Physiol Regul Integr Comp Physiol. (2009) 297:R525-45. doi: 10.1152/ajpregu.00153.2009

8. Hamilton S, Oomomian Y, Stephen G, Shynlova O, Tower CL, Garrod A, et al. Macrophages infiltrate the human and rat decidua during term and preterm labor: evidence that decidual inflammation precedes labor. Biol Reprod (2012) 39:31-9. doi: 10.1095/biolreprod.111.095505

9. Singh N, Herbert B, Sooranna GR, Orsi NM, Edey L, Dasgupta $\mathrm{T}$, et al. Is myometrial inflammation a cause or a consequence of term human labour? J Endocrinol. (2017) 235:69-83. doi: 10.1530/JOE17-0318

10. Lappas M, Permezel M, Rice GE. Mitogen-activated protein kinase proteins regulate LPS-stimulated release of pro-inflammatory cytokines and prostaglandins from human gestational tissues. Placenta (2007) 28:936-45. doi: 10.1016/j.placenta.2007.02.009

11. MacIntyre DA, Lee YS, Migale R, Herbert BR, Waddington SN, Peebles D, et al. Activator protein 1 is a key terminal mediator of inflammation-induced preterm labor in mice. FASEB J. (2014) 28:2358-68. doi: 10.1096/fj.13-247783

12. Lindstrom TM, Bennett PR. The role of nuclear factor kappa B in human labour. Reproduction (2005) 130:569-81. doi: 10.1530/rep. 1.00197

13. Perkins ND. Integrating cell-signalling pathways with NF-kappaB and IKK function. Nat Rev Mol Cell Biol. (2007) 8:49-62. doi: 10.1038/nrm2083

14. Cookson VJ, Chapman NR. NF-kappaB function in the human myometrium during pregnancy and parturition. Histol Histopathol. (2010) 25:945-56. doi: 10.14670/HH-25.945

15. Orange JS, May MJ. Cell penetrating peptide inhibitors of nuclear factorkappa B. Cell Mol Life Sci. (2008) 65:3564-91. doi: 10.1007/s00018-008-8222-Z would like to acknowledge the hard work and dedication of the research and midwifery team plus the medical staff at the Royal Victoria Infirmary Maternity Department for their assistance in recruitment, sample collection and supporting the efforts of young researchers.

\section{SUPPLEMENTARY MATERIAL}

The Supplementary Material for this article can be found online at: https://www.frontiersin.org/articles/10.3389/fimmu. 2018.02966/full\#supplementary-material

16. Hayden MS, Ghosh S. Signaling to NF-kappaB. Genes Dev. (2004) 18:2195224. doi: $10.1101 / \operatorname{gad} .1228704$

17. Belt AR, Baldassare JJ, Molnar M, Romero R, Hertelendy F. The nuclear transcription factor NF-kappaB mediates interleukin-1beta-induced expression of cyclooxygenase-2 in human myometrial cells. Am J Obstet Gynecol. (1999) 181:359-66. doi: 10.1016/S0002-9378(99)70562-4

18. Gibb W. The role of prostaglandins in human parturition. Ann Med. (1998) 30:235-41. doi: 10.3109/07853899809005850

19. Soloff MS, Cook DLJr, Jeng YJ, Anderson GD. In situ analysis of interleukin1-induced transcription of cox-2 and il-8 in cultured human myometrial cells. Endocrinology (2004) 145:1248-54. doi: 10.1210/en.2003-1310

20. Choi SJ, Oh S, Kim JH, Roh CR. Changes of nuclear factor kappa B (NFkappaB), cyclooxygenase-2 (COX-2) and matrix metalloproteinase-9 (MMP9) in human myometrium before and during term labor. Eur J Obstet Gynecol Reprod Biol. (2007) 132:182-8. doi: 10.1016/j.ejogrb.2006.07.024

21. Lye SJ, Nicholson BJ, Mascarenhas M, MacKenzie L, Petrocelli T. Increased expression of connexin-43 in the rat myometrium during labor is associated with an increase in the plasma estrogen:progesterone ratio. Endocrinology (1993) 132:2380-6. doi: 10.1210/endo.132.6.8389279

22. Terzidou V, Lee Y, Lindstrom T, Johnson M, Thornton S, Bennett PR. Regulation of the human oxytocin receptor by nuclear factor-kappaB and CCAAT/enhancer-binding protein-beta. J Clin Endocrinol Metab. (2006) 91:2317-26. doi: 10.1210/jc.2005-2649

23. Haas DM, Caldwell DM, Kirkpatrick P, McIntosh JJ, Welton NJ. Tocolytic therapy for preterm delivery: systematic review and network meta-analysis. BMJ (2012) 345:e6226. doi: 10.1136/bmj.e6226

24. Fosgerau K, Hoffmann T. Peptide therapeutics: current status and future directions. Drug Discov Today (2015) 20:122-8. doi: 10.1016/j.drudis.2014.10.003

25. Copolovici DM, Langel K, Eriste E, Langel U. Cell-penetrating peptides: design, synthesis, and applications. ACS Nano (2014) 8:1972-94. doi: $10.1021 / \mathrm{nn} 4057269$

26. Jones AT, Sayers EJ. Cell entry of cell penetrating peptides: tales of tails wagging dogs. J Control Release (2012) 161:582-91. doi: 10.1016/j.jconrel.2012.04.003

27. Marqus S, Pirogova E, Piva TJ. Evaluation of the use of therapeutic peptides for cancer treatment. J Biomed Sci. (2017) 24:21. doi: 10.1186/s12929-017-0328-x

28. Guidotti G, Brambilla L, Rossi D. Cell-penetrating peptides: from basic research to clinics. Trends Pharmacol Sci. (2017) 38:406-24. doi: 10.1016/j.tips.2017.01.003

29. May MJ, D’Acquisto F, Madge LA, Glockner J, Pober JS, Ghosh S. Selective inhibition of NF-kappaB activation by a peptide that blocks the interaction of NEMO with the IkappaB kinase complex. Science (2000) 289:1550-4. doi: 10.1126/science.289.5484.1550

30. Reay DP, Yang M, Watchko JF, Daood M, O'Day TL, Rehman KK, et al. Systemic delivery of NEMO binding domain/IKKgamma inhibitory peptide to young $\mathrm{mdx}$ mice improves dystrophic skeletal muscle histopathology. Neurobiol Dis. (2011) 43:598-608. doi: 10.1016/j.nbd.2011. 05.008

31. McCorkell KA, May MJ. NEMO-binding domain peptide inhibition of inflammatory signal-induced NF-kappaB activation in vivo. Methods Mol Biol. (2015) 1280:505-25. doi: 10.1007/978-1-4939-2422-6_30 
32. Roy A, Mondal S, Kordower JH, Pahan K. Attenuation of microglial RANTES by NEMO-binding domain peptide inhibits the infiltration of CD8 T cells in the nigra of hemiparkinsonian monkey. Neuroscience (2015) 302:36-46. doi: 10.1016/j.neuroscience.2015.03.011

33. Gupta SC, Sundaram C, Reuter S, Aggarwal BB. Inhibiting NFkappaB activation by small molecules as a therapeutic strategy. Biochim Biophys Acta (2010) 1799:775-87. doi: 10.1016/j.bbagrm.2010. 05.004

34. Mandery K, Glaeser H, Fromm MF. Interaction of innovative small molecule drugs used for cancer therapy with drug transporters. Br J Pharmacol. (2012) 165:345-62. doi: 10.1111/j.1476-5381.2011.01618.x

35. Kishore N, Sommers C, Mathialagan S, Guzova J, Yao M, Hauser S, et al. A selective IKK-2 inhibitor blocks NF-kappa B-dependent gene expression in interleukin-1 beta-stimulated synovial fibroblasts. J Biol Chem. (2003) 278:32861-71. doi: 10.1074/jbc.M211439200

36. De Silva D, Mitchell MD, Keelan JA. Inhibition of choriodecidual cytokine production and inflammatory gene expression by selective IkappaB kinase (IKK) inhibitors. Br J Pharmacol. (2010) 160:1808-22. doi: 10.1111/j.1476-5381.2010.00839.x

37. Karolczak-Bayatti M, Sweeney M, Cheng J, Edey L, Robson SC, Ulrich SM, et al., (2011). Acetylation of heat shock protein 20 (Hsp20) regulates human myometrial activity. J Biol Chem. 286:34346-55. doi: 10.1074/jbc.M111.278549

38. Khaja KRP. Comparison of functional protein transduction domains using the NEMO binding domain peptide. Pharmaceuticals (2010) 3:110-24. doi: 10.3390/ph3010110

39. Khammanit R, Chantakru S, Kitiyanant Y, Saikhun J. Effect of serum starvation and chemical inhibitors on cell cycle synchronization of canine dermal fibroblasts. Theriogenology (2008) 70:27-34. doi: 10.1016/j.theriogenology.2008.02.015

40. Sayers EJ, Cleal K, Eissa NG, Watson P, Jones AT. Distal phenylalanine modification for enhancing cellular delivery of fluorophores, proteins and quantum dots by cell penetrating peptides. J Control Release (2014) 195:55-62. doi: 10.1016/j.jconrel.2014.07.055

41. Challis JRG, Matthews SG, Gibb W, Lye SJ. Endocrine and paracrine regulation of birth at term and preterm. Endocr Rev. (2000) 21:514-50. doi: 10.1210/er.21.5.514

42. Webster SJ, Waite SL, Cookson VJ, Warren A, Khan R, Gandhi $\mathrm{SV}$, et al. Regulation of GTP-binding protein (Galphas) expression in human myometrial cells: a role for tumor necrosis factor in modulating Galphas promoter acetylation by transcriptional complexes. J Biol Chem. (2013) 288:6704-16. doi: 10.1074/jbc.M112. 440602

43. Chan YW, van den Berg H. A, Moore JD, Quenby S, Blanks AM. Assessment of myometrial transcriptome changes associated with spontaneous human labour by high-throughput RNA-seq. Exp Physiol. (2014) 99:510-24. doi: 10.1113/expphysiol.2013.072868

44. Sakowicz A. The role of NFkappaB in the three stages of pregnancy - implantation, maintenance, and labour: a review article. BJOG (2018) 125:1379-87. doi: 10.1111/1471-0528.15172

45. Stinson LF, Ireland DJ, Kemp MW, Payne MS, Stock SJ, Newnham JP, et al. Effects of cytokine-suppressive anti-inflammatory drugs on inflammatory activation in ex vivo human and ovine fetal membranes. Reproduction (2014) 147:313-20. doi: 10.1530/REP-13-0576

46. Gautam A, Singh H, Tyagi A, Chaudhary K, Kumar R, Kapoor P, et al. CPPsite: a curated database of cell penetrating peptides. Database (2012) 2012:bas015. doi: 10.1093/database/bas015

47. Wender PA, Mitchell DJ, Pattabiraman K, Pelkey ET, Steinman L, Rothbard JB. The design, synthesis, and evaluation of molecules that enable or enhance cellular uptake: Peptoid molecular transporters. Proc Natl Acad Sci USA. (2000) 97:13003-8. doi: 10.1073/pnas.97.24.13003

48. Christiaens B, Grooten J, Reusens M, Joliot A, Goethals M, Vandekerckhove J, et al., (2004). Membrane interaction and cellular internalization of penetratin peptides. Eur J Biochem. 271:1187-97. doi: 10.1111/j.1432-1033.2004.04022.x

49. Fischer PM, Zhelev NZ, Wang S, Melville JE, Fåhraeus R, Lane DP. Structure-activity relationship of truncated and substituted analogues of the intracellular delivery vector Penetratin. J Peptide Res. (2000) 55:163-72. doi: 10.1034/j.1399-3011.2000.00163.x

50. Israël A. The IKK Complex, a Central Regulator of NF-кB Activation. Cold Spring Harb Perspect Biol. (2010) 2:a000158. doi: 10.1101/cshperspect.a000158

51. Bollopragada S, Youssef R, Jordan F, Greer I, Norman J, Nelson S. Term labor is associated with a core inflammatory response in human fetal membranes, myometrium, and cervix. Am J Obst Gynecol. (2009) 200:104.e101-104.e111. doi: 10.1016/j.ajog.2008.08.032

52. Mittal P, Romero R, Tarca AL, Gonzalez J, Draghici S, Xu Y, et al. Characterization of the myometrial transcriptome and biological pathways of spontaneous human labor at term. J Perinat Med. (2010) 38:617-43. doi: 10.1515/jpm.2010.097

53. Ng PY, Ireland DJ, Keelan JA. Drugs to block cytokine signaling for the prevention and treatment of inflammation-induced preterm birth. Front Immunol. (2015) 6:166. doi: 10.3389/fimmu.2015.00166

54. Garcia-Flores V, Romero R, Miller D, Xu Y, Done B, Veerapaneni C, et al. Inflammation-induced adverse pregnancy and neonatal outcomes can be improved by the immunomodulatory peptide exendin-4. Front Immunol. (2018) 9:1291. doi: 10.3389/fimmu.2018.01291

55. King A, Ndifon C, Lui S, Widdows K, Kotamraju VR, Agemy L, et al. Tumorhoming peptides as tools for targeted delivery of payloads to the placenta. Sci $A d v$. (2016) 2:e1600349. doi: 10.1126/sciadv.1600349

56. Beards F, Jones LE, Charnock J, Forbes K, Harris LK. Placental homing peptide-microRNA inhibitor conjugates for targeted enhancement of intrinsic placental growth signaling. Theranostics (2017) 7:2940-55. doi: $10.7150 /$ thno. 18845

Conflict of Interest Statement: The authors declare that the research was conducted in the absence of any commercial or financial relationships that could be construed as a potential conflict of interest.

Copyright (c) 2018 Gurney, Taggart, Tong, Jones, Robson and Taggart. This is an open-access article distributed under the terms of the Creative Commons Attribution License (CC BY). The use, distribution or reproduction in other forums is permitted, provided the original author(s) and the copyright owner(s) are credited and that the original publication in this journal is cited, in accordance with accepted academic practice. No use, distribution or reproduction is permitted which does not comply with these terms. 